$\tilde{\tilde{X}}=\frac{\Delta \tilde{\tilde{X}}_{j}}{\Delta X_{j}} X+$

$$
+\frac{\Delta X_{j} \tilde{\tilde{X}}_{\min }+\Delta X_{j} \sum_{k=1}^{j-1} \Delta \tilde{\tilde{X}}_{k}-X_{\min } \sum_{k=1}^{j} \Delta \tilde{\tilde{X}}_{k}-X_{\min } \tilde{\tilde{X}}_{j}-\Delta \tilde{\tilde{X}}_{k} \sum_{k=1}^{j-1} \Delta \tilde{\tilde{X}}_{k}}{\Delta X_{k}} .
$$

Окремим випадком кусково-лінійного нормування (при кількості ділянок $N=1$ ) є лінійне нормування, яке було розглянуте вище.

\section{4. Висновки}

Представлені методи перетворення показників дозволяють забезпечити порівнянність числових значень показників при оцінюванні та отримувати нормовані оцінки 3 урахуванням вимог, які виражають переваги осіб, які використовують результати оцінювання для ухвалення рішень і є зацікавленими в пов'язанні правил оцінки з прагматичними цілями.

\section{Література}

1. Долгов, О. І. Коефіцієнтна методика оцінювання навчальновиховного процесу [Текст] // О. І. Долгов, О. О. Прокопенко, Н. С. Антоненко // Проблеми інженерно-педагогічної освіти. - Харків: УІПА, 2012. - № 37. - С. 202-206.

2. Гордій, М. П. Рейтингова оцінка діяльності викладача коледжу [Електронний ресурс] / М. П. Гордій. - Режим доступу: \www/URL: http://www.udau.edu.ua/ua/departments/ koledzhi/shevchenkivskij-koledzh/ rejtingova-oczinka-diyalnostivikladacha-koledzhu.html

3. Положення про рейтингове оцінювання викладача, кафедри, факультету у Східноєвропейському національному університеті імені Лесі Українки [Електронний ресурс]. - 2013. Режим доступу: \www/URL: http://ed.eenu.edu.ua/documents

4. Берлінські принципи ранжирування вузів [Електронний ресурс] / Сайт Центру міжнародних проектів «Евроосвіта». - 2006. - Режим доступу: \www/URL: http://www. euroosvita.net/index.php/?category $=1 \& \mathrm{id}=437$

5. Про затвердження Положення про національну систему рейтингового оцінювання загальноосвітніх навчальних закладів. Наказ Міністерства освіти і науки України № 1058 від 01.08.2013 [Электронный ресурс]. - 2013 - Режим доступа: www/URL: http://zakon4.rada.gov.ua/laws/show/z1362-13

6. Болотов, В. А. Система оценки качества российского образования [Текст] / В. А. Болотов, Н. Ф. Ефремова [Электрон- ный ресурс]. - M., 2005. - Режим доступа: \www/URL: http://www.den-za-dnem.ru/page.php?article $=150$

7. Методология систем рейтинговых оценок [Текст] // Экопедия. 2011 [Электронный ресурс]. - Режим доступа: www/URL: http://ecorussia.info

8. Конев, К. А. Интегрированная система рейтинговой оценки качества образования [Электронный ресурс] / К. А. Конев, Г. В. Старцев // Вестник УГАТУ. - 2009. - Режим доступа: \www/URL: http://old.ugatu.ac.ru/publish /vu/stat/ ugatu-2009-1\%2830\%29/14.pdf

9. Долгов, А. И. Обработка показателей в компьютерных методиках оценки образовательного процесса [Текст] / А. И. Долгов, А. Ф. Мартыненко, В. В. Преснухин // Программные продукты и системы. - 2012. - N 1. - С. 107-111. ISSN 0236-235X

10. Долгов, А. И. Метод кусочно-линейной рейтинговой нормализации [Текст] / А. И. Долгов // Автоматика и вычислительная техника. - 2006. - № 3. - С. 24-32.

\section{ПРЕОБРАЗОВАНКЕ ПОКАЗАТЕЛЕЙ ЛРИ РЕЙТИНГОВОЙ ОЦЕНКЕ}

В работе решена задача обеспечения сравнимости числовых значений показателей (в том числе и количественно-качественных) при оценивании широкого круга объектов. Представлен метод обработки показателей, в частности приведения неограниченной области их определения к ограниченной, который основан на нормировании.

Ключевые слова: оценивание, рейтинговая оценка, сравнимость показателей, кусочно-линейное нормирование, область определения показателя.

Долгов Олександр Іванович, доктор технічних наук, профе сор, кафедра обчислювальної системи і інформаційної безпеки, Донськой державний технічний університет, Росія,

e-mail: dolgov-ai@yandex.ru.

Прокопенко Олена Олександрівна, кандидат технічних наук, доцент, кафедра систем управління, Украйнська інженернопедагогічна академія, Харків, Україна, е-таil: digaz@i.ua.

Долгов Александр Иванович, доктор технических наук, профессор, кафедра вычислительной системы и информационной безопасности, Донской государственный технический университет, Россия.

Прокопенко Елена Александровна, кандидат технических наук, дочент, кафедра систем управления, Украинская инженерно-педагогическая академия, Харьков, Украина.

Dolgov Alexandr, Don State Technical University, Russia, e-mail: dolgov-ai@yandex.ru.

Prokopenko Olena, Ukrainian Engineering Pedagogics Academy, Kharkiv, Ukraine, e-mail: digaz@i.ua

УДК 656.057.87+343.983.2

Шawra I. K., Сікоринський В. В.

\section{ОЦІККА ЗАЛЕЖНОСТІ ВИТРАТИ ПАЛЬНОГО В ОСОБЛИВИХ УМОВАХ ЕКСПЛУАТАЦIї}

Представлено аналіз оціночних показників, які впливають на витрату пального автобронетанковою технікою в особливих умовах експлуатаціі. Наведено обмеження, які притаманні спещифіщі використання машин при виконанні службово-бойових завдань. Запропоновано шляхи удосконалення існуючої математичної моделі витрати пального.

Ключові слова: витрата пального, особливі умови експлуатацї, математична модель, автобронетанкова техніка.

\section{1. Ветул}

В ході службово-бойової діяльності внутрішніх військ виникає необхідність в переміщенні частин та підрозділів в пункти службово-бойового призначення. При цьому використовується значна кількість пального. Для розрахунку норм його витрати розроблено низку 
методів, які грунтуються на відомих математичних моделях. Але специфіка застосування автобронетанкової техніки внутрішніх військ при здійсненні правоохоронної діяльності значно відрізняється від використання машин у звичайних умовах національної економіки.

\section{2. Аналіз літературних даних і постановка проблеми}

Аналіз літературних джерел показує, що діюча в теперішній час методика нормування витрати пального є емпіричною, тому що базується в основному на експериментальних даних. Практично відсутня об'єктивна оцінка умов експлуатації машин. Норми недостатньо диференційовані по умовам роботи машин. При розбиранні окремих норм встановлюється своя класифікація, по різному враховується зовнішня дія дороги та атмосфери. Відсутність єдиних критеріїв умов експлуатації. Сучасні машини, які експлуатуються в теперішній час достатньо інформатизовані. Але ще багато машин експлуатується не обладнаних бортовими приладами, які регіструють виконану роботу та умови експлуатації. Із спеціальної літератури відомі різні рівняння витрати пального, які могли бути використані при нормуванні витрати пального. Економічна характеристика автомобіля, запропонована академіком Є. А. Чудаковим [1] є зручним критерієм для порівнювальної оцінки економічних якостей автомобілів, але до експлуатаційної мети вона не придатна, тому що не враховує змінні навантаження, дорожні умови та інші фактори. П. І. Козловський [2] пропонував витрати пального приймати прямо пропорційно навантаженню двигуна в інтервалах навантажень: $0-25,25-50,50-75,75-90$ та $90-100 \%$.

Професор Л. В. Клименко приймав лінійну залежність годинної витрати пального від навантаження двигуна [3]. Н. А. Яковлєв у своїх дослідженнях по питанню економічності авто потягів також приймав подібну залежність [4]. Він рахував, що при використанні потужності двигуна до 50.....60 \% між витратою пального та величиною використання потужності існує лінійна залежність. Доктор технічних наук Д. А. Рубец [5] приймав, що витрата пального при середніх та підвищених навантаженнях змінюються в залежності від потужності при постійних частотах обертання колінчастого валу двигуна по закону, близькому до лінійного. 3 зарубіжної літератури відомі математичні моделі різної складності для визначення витрати пального автомобіля. Найбільш складні моделі визначають витрату пального за кожну секунду та включають опис його зміни при відкритті та закритті дросельної заслінки і інших операціях. В протилежність цьому існують математичні моделі, за допомогою яких визначається середня величина витрати пального за дорожній цикл, наприклад цикл AS 2077 рух в міських умовах. Ступінь складності моделі залежить від поставленого завдання. Якщо ставиться завдання оптимізації конструкції окремого автомобіля, розробляються математичні моделі витрати пального, в яких враховуються всі параметри автомобіля, впливаючи на витрату пального, такі як маса, втрати в трансмісіі, аеродинамічний опір, опір коченню та інш. Прикладом такої математичної моделі може служити рівняння, отримане в результаті експериментальних досліджень автомобіля FORD з шести циліндровим двигуном робочим об'ємом циліндрів 4,1 л. Автомобіль був споряджений всіма необхідними вимірювальними приладами. Витрата пального замірювалася розходометром об'ємного типу Pierburq PLU 106. Показники приладу передавалися на аналого-цифровий перетворювач, а комп'ютер видав чисельні данні. Пробіг проходив в Мельбурні на швидкісних трасах, магістралях і магістралях з світлофорами, регульованими комп'ютером. Результати експерименту показали достатньо точне наближення до математичної моделі [6].

Теоретичною основою розрахунково-аналітичного метода визначення індивідуальних лінійних норм витрати пального є аналітичні залежності, які встановлюються в результатах сумісного рішення рівняння руху автомобіля і паливних характеристик двигуна. Найдосконала математична модель розроблена професором Шашою І. К. [7] , вона в найбільш повній мірі враховує експлуатаційні та конструктивні фактори, які впливають на витрату пального колісними машинами. Вона базується на основних залежностях, відомих з механіки руху автомобіля теорії двигуна.

У загальному вигляді рівняння витрати пального записується в такому вигляді:

$Q=\frac{1}{\eta_{i}}\left[A i_{k}+B i k^{2} V a+C\left(G a \psi+0,077 k F V^{2} a \pm 0,1 \beta G a \dot{V} a\right)\right]$ л/100 км,

де $A, B$ і $C$ - постійні коефіцієнти для даного автомобіля; $\eta_{i}-$ ККД індикаторний двигуна; $i_{k}-$ передаточне число коробки передач; $V a-$ швидкість автомобіля, км/ч; $G a-$ вага автомобіля, Н; $\Psi$ - коефіцієнт сумарного дорожнього опору; $k F-$ фактор оптічності автомобіля, $\mathrm{Hc}^{2} \mathrm{M}^{-2} ; \dot{V} a-$ прискорення (уповільнення) автомобіля, м².

Результати експерименту показали достатньо добрі наближення до математичної моделі витрати пального.

Метою проведених досліджень $є$ проведення оцінки залежності витрати пального в особливих умовах експлуатації для удосконалення математичної моделі та подальшого розвитку методу розрахунку витрати пального.

Для досягнення поставленої мети необхідно було вирішити наступні основні задачі: оцінити вплив основних експлуатаційних та конструктивних факторів на витрату пального в особливих умовах експлуатації; прийняти обмеження, які дозволять в подальшому удосконалити математичну модель розрахунку витрати пального, яка на відміну від існуючих враховує фактори особливих умов експлуатації.

\section{3. Результати досліджень процесу експлуатації автобронетанкової техніки}

Об’єктом досліджень був вибраний процес експлуатації автобронетанкової техніки в особливих умовах.

Враховуючи особливості експлуатації автобронетанкової техніки, яка стоїть на озброєнні частин та підрозділів внутрішніх військ МВС України слід зауважити, що при розрахунках витрати пального не враховується передаточне число роздавальної коробки у автомобілів високої прохідності. Аналізуючи особливості застосування автобронетанкової техніки внутрішніх військ з'ясовано, що на відміну від цивільних підприємств, де $\mathrm{V}$ група доріг передбачає використання тракторів, службово-бойові завдання виконують автомобілі, також VI-VII групи умов експлуатації не є винятком [8]. 
Цей факт говорить про те, що необхідно провести оцінку залежності витрати пального в особливих умовах експлуатації з подальшим удосконаленням математичної моделі. Найбільш економічним є режим руху автомобіля коли $i_{k} \leq 1$, а швидкість постійна та не перевищує $(0,6 \ldots 0,7) \quad V_{\max }[9]$, але це твердження не підпадає під умови експлуатації автобронетанкової техніки внутрішніх військ. Середнє значення $i_{k}-$ можливо визначити двома методами: за змінами швидкості і значенню навантаження [10].

Перший метод описано формулою:

$$
i_{k}=\frac{0,377 r_{k} K_{c} \eta_{N}}{i_{0} V_{a}}
$$

де $K_{c}$ - швидкісний коефіцієнт; $\eta_{N}-$ максимальна частота обертів колінчастого валу.

Другий метод:

$$
i_{k}=\frac{r_{k}}{M_{k} \eta_{\mathrm{Tp}} i_{0}}\left(G_{a} \varphi+0,077 k F V_{a}^{2}\right) \text {. }
$$

Так як VI-VII групи умов експлуатації обумовлені переміщенням на швидкостях до 40 км/год, то опором повітря можливо знехтувати тобто не враховувати цей показник в процесі удосконалення математичної моделі витрати пального. В процесі дослідження приймаємо наступні обмеження, щодо подальшого розвитку основної математичної моделі.

Для дорожніх і транспортних умов наведено відносні межі зміни середніх технічних швидкостей. Ці межі встановлено на основі теоретичних та експериментальних досліджень. Коефіциент одиниця відповідає швидкості $0,7 V_{\max }$. Тому для VI-VII групи умов експлуатації приймаємо наступні межі швидкості $(0,20-0,14) V_{\max }$ для VI групи експлуатації, $(0,14-0,10)$.

\section{4. Висновки}

Проведена оцінка залежності витрати пального дала основу подальшої роботи, щодо удосконалення відомої математичної моделі витрати пального. Результати досліджень дали напрямок подальшого розвитку методу розрахунку витрати пального в особливих умовах експлуатаціі.

\section{Література}

1. Чудаков, Е. А. Пути повышения экономичности автомобиля [Текст] / Е. А. Чудаков // Отделение технических наук. - М.-Л.: Изд. АН СССР, 1948. - № 12. - 94 с.

2. Козловски, П. И. Расчет скорости движения автомобиля и расхода горючого [Текст] / П. И. Козловски. - Л.: Гострансиздат, 1939. - 136 с.
3. Клименко, Л. В. Проэктирование автотранспортных двигателей карбюраторного типа [Текст] / Л. В. Клименко. - Л.: Гострансиздат, 1937. - 350 с.

4. Яковлев, Н. А. Теория автомобіля [Текст] / Н. А. Яковлев, Н. В. Диваков. - Х.: ХГУ, 1989. - 188 с.

5. Рубец, Д. А. Смесеобразование в автомобильном двигателе при переменных режимах [Текст] / Д. А. Рубец. - М.: Машгиз, 1948. - 254 с.

6. Упрощенный метод расчета расхода топлива при движение автомобиля в городских условиях [Текст] / SEA Australia. 1980. - № 1. -6 c.

7. Шаша, І. К. Совершенствование действующей системы нормирования расхода топлива грузовых автомобилей [Текст] : дис. на соиск. науч. степ. канд. техн. наук / І. К. Шаша. 1991. - С. 47.

8. Топчій, Р. І. Підвищення ефективності використання спеціальної колісної техніки підрозділами внутрішніх військ за рахунок встановлення закономірностей впливу особливих умов експлуатіції на експлуатаційні показники [Текст] : дис. на здоб. наук. ступ. канд. техн. наук / Р. I. Топчій. - 2012. - С. 90.

9. Говорущенко, Н. Я. Экономическая кибернетика транспорта [Текст] / Н. Я. Говорущенко, В. Н. Варфоломеев. - Харьков: РИО ХГАДТУ, 2000. - 218 с.

10. Говорущенко, Н. Я. Экономия топлива и снижение токсичности на автомобильном транспорте [Текст] / Н. Я. Говорущенко. - М: Транспорт, 1990. - 135 с.

\section{ОЦЕНКА ЗАВИСИМОСТИ РАСХОДА ТОПЛИВА В ОСОБЫХ УсЛОВИЯХ ЭКСПЛУАТАЦИИ}

Представлен анализ оценочных показателей, которые влияют на расход топлива автобронетанковой техникой в особых условиях эксплуатации. Приведены ограничения, которые присущи специфике использования машин при выполнении служебнобоевых задач. Предложено пути усовершенствования существующей математической модели расхода топлива.

Ключевые слова: расход топлива, особые условия эксплуатации, математическая модель, автобронетанковая техника.

Шаша Ігор Костянтинович, доктор технічних наук, професор кафедра експлуатацї $і$ ремонту автомобілів та бойових машин, Академія внутрішніх військ МВС України, Харків, Украйна. Сікоринский Віталій Валерійович, ад'юнкт, кафедра експлуатаиї $і$ ремонту автомобілів та бойових машин, Академія внутрішніх військ МВС України, Харків, Україна.

Шаша Игорь Константинович, доктор технических наук, профессор, кафедра эксплуатации и ремонта автомобилей и боевых машин, Академия внутренних войск МВД Украины, Харьков, Украина.

Сикоринский Виталий Валервевич, адбюнкт, кафедра эксплуатации и ремонта автомобилей и боевых машин, Академия внутренних войск МВД Украины, Харьков, Украина.

Shasha Igor, Academy of the Interior Troops of the Ministry of Internal Affairs of Ukraine, Kharkiv, Ukraine.

Sikorinskiy Vitaliy, Academy of the Interior Troops of the Ministry of Internal Affairs of Ukraine, Kharkiv, Ukraine 